\title{
Regulation of connexin 43 and microRNA expression via $\beta 2$-adrenoceptor signaling in 1321N1 astrocytoma cells
}

\author{
MOJTABA KHAKSARIAN ${ }^{1-3}$, HOSSEIN MOSTAFAVI $^{3,4}$, MASOUD SOLEIMANI $^{3,5}$, SEID MORTEZA KARIMIAN ${ }^{6}$, \\ MOHAMMAD HASSAN GHAHREMANI ${ }^{7}$, MOHAMMAD TAGHEE JOGHATAEE $^{8}$, MOHSEN KHORASHADIZADEH $^{9}$, \\ HADI ALIGHOLI $^{2}$, FATEMEH ATTARI ${ }^{2}$ and GHOLAMREZA HASSANZADEH ${ }^{2,10}$
}

\author{
${ }^{1}$ Department of Physiology, School of Medicine, Lorestan University of Medical Sciences, Khorramabad 6814993165; \\ ${ }^{2}$ Department of Neuroscience, School of Advanced Medical Technologies, Tehran University of Medical Sciences, \\ Tehran 1417743371; ${ }^{3}$ Department of Molecular Biology and Genetic Engineering, Stem Cell Technology Research Center, \\ Tehran 1997775555; ${ }^{4}$ Department of Physiology, School of Medicine, Zanjan University of Medical Sciences, Zanjan 4513956111; \\ ${ }^{5}$ Department of Hematology, Tarbiat Modares University, Tehran 14115331; ${ }^{6}$ Department of Physiology, School of Medicine, \\ Tehran University of Medical Sciences, Tehran 1417613151; ${ }^{7}$ Department of Molecular Medicine, School of \\ Advanced Medical Technologies, Tehran University of Medical Sciences, Tehran 1417743371; \\ ${ }^{8}$ Department of Anatomy, School of Medicine, Iran University of Medical Sciences, Tehran 1417755469; \\ ${ }^{9}$ Department of Medical Biotechnologies, School of Advanced Medical Technologies, Tehran University of \\ Medical Sciences, Tehran 1417743371; ${ }^{10}$ Department of Anatomy, School of Medicine, \\ Tehran University of Medical Sciences, Tehran 1417613151, Iran
}

Received February 10, 2014; Accepted December 12, 2014

DOI: $10.3892 / \mathrm{mmr} .2015 .3609$

\begin{abstract}
Connexin 43 (Cx43) is the main gap junction protein in astrocytes and exerts the same effects on growth inhibition in astrocytoma and glioma as microRNA-146a (miR-146a) in glioma. $\beta 2$-adrenergic receptor (AR) signaling modulates $\mathrm{Cx} 43$ expression in myocytes via components downstream of protein kinase A (PKA) and exchange protein directly activated by cAMP (Epac). However, it remains to be elucidated how expression of $\mathrm{Cx} 43$ is modulated in astrocytes. In the present study, $1321 \mathrm{~N} 1$ astrocytoma cells were treated with $\beta 2$-AR signaling agents in order to evaluate the expression of Cx43 and miRNAs. RNA and protein were extracted from the cells for use in reverse transcription-quantitative polymerase chain reaction and western blot analysis, respectively. The results revealed that clenbuterol increased miR-146a level and upregulated Cx43 expression via cAMP/PKA at the mRNA and protein level. Pre-inhibition of adenyl cyclase decreased expression of Cx43 and miR-146a. PKA activation and overexpression of miR-146a in A-1321N1 cells increased the expression of $\mathrm{Cx} 43$. $\beta 2-\mathrm{AR}$ stimulation and 6Bnz, a PKA activator, suppressed oncomiRs miR-155
\end{abstract}

Correspondence to: Professor Gholamreza Hassanzadeh, Department of Anatomy, School of Medicine, Tehran University of Medical Sciences, Poursina Street, Tehran 1417613151, Iran

E-mail: hassanzadeh@tums.ac.ir

Key words: $\beta 2$-adrenoceptor, 1321N1 astrocytoma cell, connexin 43, microRNA and miR-27a, while 8-(4-chlorophenylthio)-2'-O-methyl adenosine-3',5'-cyclic monophosphate, an Epac activator, increased their levels. The current findings demonstrated that $\beta 2$-AR signaling has growth inhibitory effects via modulation of the cAMP/PKA pathway in A-1321N1 cells through increasing the expression level of $\mathrm{Cx} 43$ and miR-146a as well as decreasing miR-155 and miR-27a levels. Thus, stimulation of the $\beta 2-A R$ and PKA signaling pathway may be a useful approach for astrocytoma therapy.

\section{Introduction}

The majority of malignant brain tumors are astrocytoma or glioma, which are often fatal with a median survival time from diagnosis of $\sim 15$ months (1). Connexins (Cxs), particularly Cx43 (2) and certain microRNAs $(3,4)$ are important in the modulation of astrocytoma and glioma. Since current clinical approaches, including surgery, chemotherapy and radiotherapy do not have a significant impact on patient survival (5), it is crucial to develop new therapeutic methods and drugs for the treatment of these diseases. Cx43 is the major Cx in astrocytes and is involved in cell cycle regulation and growth modulation (2). Cx43 has inhibitory effects on astrocytoma (6) and glioma progression (4). In addition, Cx43 enhances apoptotic effects (7-9). Cx43 expression is decreased in astrocytoma and glioma (10). In this regard, downregulation and upregulation of Cx43 leads to enhanced and decreased development of tumor malignancies, respectively $(5,11,12)$.

miRNAs are small, non-coding RNAs of 19-24 nucleotides in length that regulate gene expression and are significantly associated with either tumor development or suppression (13). 
miRNAs have been associated with several types of cancer, including glioma and its aggressive glioblastoma subtype (14). A study concerning the effects of miRNA and Cx43 expression demonstrated that miR-125b inhibits Cx43 expression and increases glioma cell development (15). However, overexpression of Cx43 inhibits the effects of miR-125b in glioma cell improvement and its anti-apoptotic effects (15). $\beta 2$-adrenergic receptor (AR) signaling upregulates $\mathrm{Cx} 43$ expression via cAMP/protein kinase A (PKA) and cAMP/exchange protein directly activated by cAMP (Epac) pathways in myocytes (16). The cAMP/PKA pathway markedly activates miR-335, which is required for differentiation therapy of C6 glioma cells (17). In this cell line, miR-146a is a glioma suppressor candidate (18), which has possible associations with $\beta 2$-AR signaling and Cx43 expression.

The current study aimed to identify the effect of $\beta 2-A R$ signaling and the role of its downstream components, adenyl cyclase inhibition, PKA activation and Epac on Cx43 expression in a human-derived astrocytoma cell line (A-1321N1). In addition, the effects of miR-146a on the overexpression of Cx43 were evaluated. Finally, the effect of the pathways downstream of $\beta 2-A R$ signaling (PKA and Epac) on the expression of miR-146a were investigated.

\section{Materials and methods}

Materials. Clenbuterol hydrochloride $(\mathrm{Cln})$, selective $\beta 2$ agonist (C5423), SQ22, 536 (SQ), adenyl cyclase inhibitor (ACi, S153), 6-Bnz-cAMP sodium salt (6Bnz), specific PKA activator (B4560), 8-(4-chlorophenylthio)-2'-O-methyladenosine-3',5'-cyclic monophosphate (8CPT), Epac-specific activator (C8988), Brefeldin (BF) and Epac inhibitor (B7651) were purchased from Sigma-Aldrich (St. Louis, MO, USA). Antibodies, including mouse monoclonal anti-connexin43/GJA1 (1:1,000; cat no. ab79010), mouse monoclonal anti- $\beta$-actin (1:5,000; cat no. ab6276), rabbit polyclonal secondary antibody to mouse $\operatorname{IgG}(1: 10,000$; cat no. ab6728) and goat polyclonal secondary antibody to rabbit IgG (1:10,000; cat no. ab6721) were all purchased from Abcam (Cambridge, MA, USA).

Cell culture and treatment. An A-1321N1 cell line was purchased from the National Cell Bank of Iran (Tehran, Iran). microRNA-146a (miR-146a) was overexpressed in this cell line. The cells were maintained in Dulbecco's modified Eagle's medium (DMEM; Gibco-BRL, Carlsbad, CA, USA) containing $10 \%$ fetal bovine serum (FBS) supplemented with $50 \mathrm{mg} / \mathrm{ml}$ streptomycin and $100 \mathrm{U} / \mathrm{ml}$ penicillin (Gibco-BRL) in a humidified atmosphere at $37^{\circ} \mathrm{C}$ and $5 \% \mathrm{CO}_{2}$. Cells in a confluent monolayer were routinely passaged by trypsinization and the passaged cells were seeded into six-well plates. The following day, the DMEM medium, containing $1 \% \mathrm{FBS}$, was changed prior to drug exposure for $24 \mathrm{~h}$. Subsequently, the cells were treated with Cln or $6 \mathrm{Bnz}$ for a further $24 \mathrm{~h}$. The Cln-treated groups of cells were pretreated in the presence or absence of SQ or BF (45 min prior to treatment with Cln) for adenyl cyclase and Epac inhibition, respectively. RNA and protein extraction were performed for reverse transcription-quantitative polymerase chain reaction (RT-qPCR) and western blot analysis, respectively.
Virus packaging and transduction. The HEK293T cell line was used for virus packaging of PB-miR-146a containing green fluorescent protein (GFP) and puromycin resistance genes. The cells were maintained in DMEM containing $10 \%$ FBS supplemented with $50 \mathrm{mg} / \mathrm{ml}$ streptomycin and $100 \mathrm{U} / \mathrm{ml}$ penicillin in a humidified atmosphere at $5 \% \mathrm{CO}_{2}$ and $37^{\circ} \mathrm{C}$. A Lentivirus packaging system containing the psPAX2 plasmid (encoding gag/pol), the pMDG plasmid (encoding VSV-G) and PB-miR-146a (as well as empty vector) were used for lentivirus production using the calcium-phosphate method (19). Subsequently, GFP expression was assessed using an inverted fluorescence microscope (Nikon TEF2000; Nikon, Tokyo, Japan) following $24 \mathrm{~h}$ of transfection. The medium containing the produced viruses was collected 24,48 and $72 \mathrm{~h}$ after transfection and kept at $4^{\circ} \mathrm{C}$. The medium was subsequently concentrated by centrifuging at $40,000 \mathrm{x}$ g at $4^{\circ} \mathrm{C}$ for $2.5 \mathrm{~h}$. Finally, the two cell lines were infected with the concentrated supernatants. At $24 \mathrm{~h}$ after transduction, the cells were treated with puromycin $(2 \mu \mathrm{g} / \mathrm{ml})$ and this treatment continued for 3 days. Negative control groups were also treated with puromycin, which, as expected, underwent cell death after $48 \mathrm{~h}$. The transfected group (PB-miR-146a) was resistant to puromycin and survived following antibiotic selection (Fig. 1).

Primer design and probe for detecting miRNAs. The sequences of miRNAs, including miR-146a, miR-155 and miR-27a were obtained from NCBI (http://www.ncbi.nlm.nih.gov/gene). Subsequently, an miRNA specific stem-loop primer was designed by adding a few complimentary nucleotides from the $3^{\prime}$ end of the miRNA to the $3^{\prime}$ end of the pre-evaluated stem-loop construction (20). qPCR was performed with an miRNA-specific forward primer, universal reverse primer and specific TaqMan probe.

RNA extraction and RT-qPCR for $m R N A$ expression. Relative quantification of gene expression of various groups of A-1321N1 cells was performed. Total RNA was isolated using QIAzol lysis reagent (Qiagen, Hilden, Germany) according to the manufacturer's instructions and used for cDNA synthesis using reverse transcriptase (cat no. RTPL12; Vivantis, Oceanside, CA, USA). Specific human primers, including GAPDH, Cx43 and cAMP response element-binding protein (CREB; Table. I) were used in these experiments with Takara SYBR Premix Ex Taq (Takara Bio, Inc., Shiga, Japan). Gene expression levels were measured using Rotor-Gene 6000 (Corbett Life Science, Concorde, NSW, Australia) and the relative expression ratio of each gene was compared with GAPDH. All data were calculated using the relative expression software tool (REST 2009.2.0.13; Qiagen).

Analyzing the expression of miRNAs using stem-loop $R T-q P C R$. Total miRNAs and specially overexpressed miR146a were extracted from A-1321N1 cells by QIAzol RNA extraction (Qiagen). For this purpose, the time and speed of centrifugation was increased to $15,000 \mathrm{x} \mathrm{g}$ for 15 min to increase the miRNA yield. Finally, extracted miRNA was dissolved in RNase-free water and stored at $-80^{\circ} \mathrm{C}$ until use. The quality was confirmed using an Eppendorf Spectrophotometer (Eppendorf AG, Hamburg, Germany). miRNA was extracted from the immortalized cell 
Table I. Sequences of human primers.

\begin{tabular}{llllcc}
\hline Gene & Accession number & \multicolumn{1}{c}{ Forward primer } & \multicolumn{1}{c}{ Reverse primer } & $\begin{array}{c}\text { Length } \\
(\mathrm{bp})\end{array}$ & $\begin{array}{c}\text { Conc } \\
(\mu \mathrm{M})\end{array}$ \\
\hline Cx43 & NM_000165.3 & GGATTGTCCTTAAGTCCCTG & CACAAGTCCATTGACACCTG & 100 & 0.4 \\
CREB & XM_005246324.1 & AACCAGCAGAGTGGAGATGCA & GGCATAGATACCTGGGCTAATGTG & 101 & 0.4 \\
GAPDH & NM_002046 & CTCTCTGCTCCTCCTGTTCG & ACGACCAAATCCGTTGACTC & 114 & 0.4 \\
\hline
\end{tabular}

Cx43, connexin 43; CREB, cAMP response element-binding protein; bp, base pair; Conc, concentration.
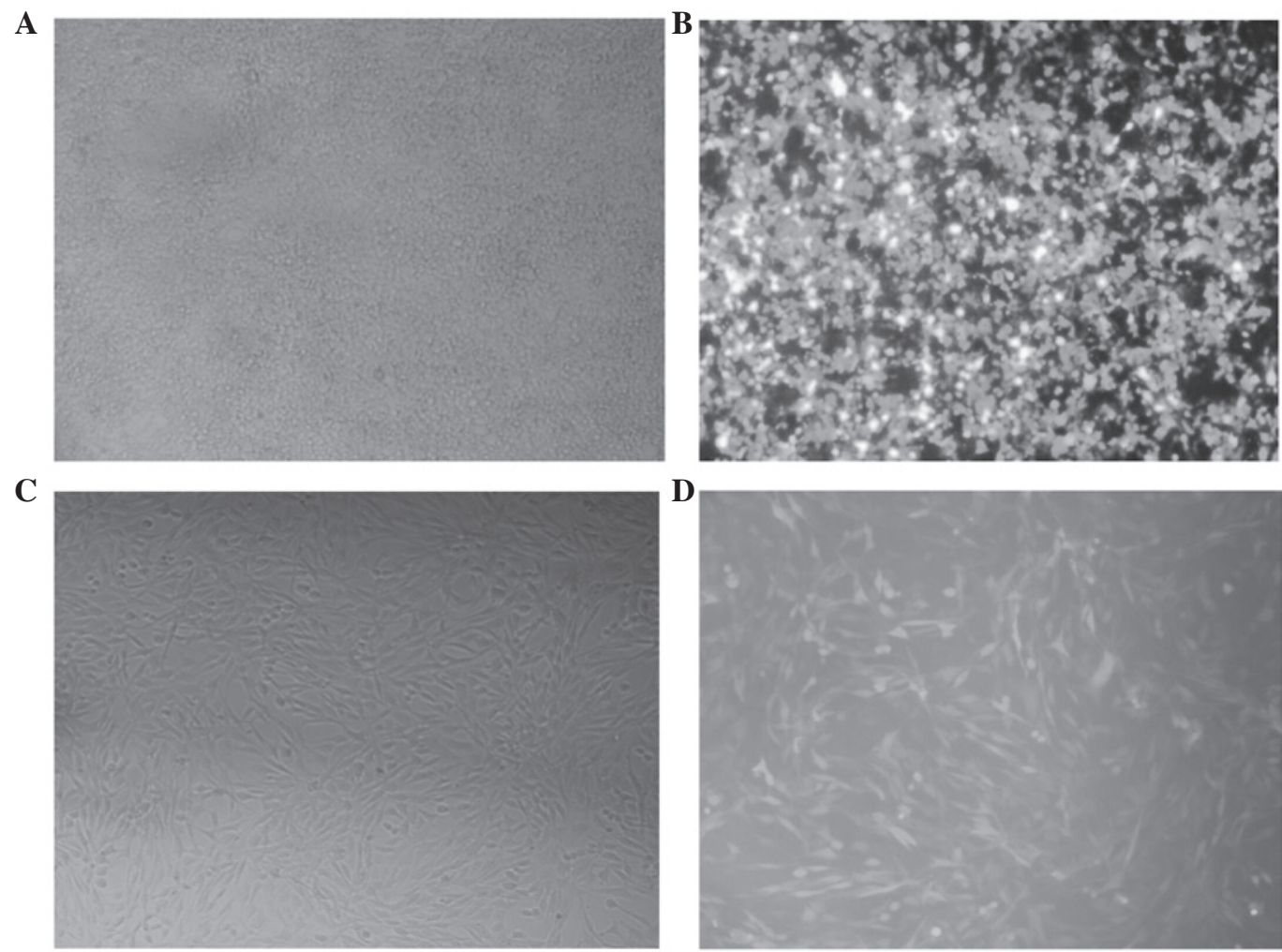

Figure 1. Transfection and transduction. HEK293T cells were transfected with vector PB-miR-146a-eGFP using the calcium-phosphate method. (A and B) Phase contrast and fluorescent image of HEK293T cells. Efficient transfection of HEK293T cells was verified by visualizing GFP expression after $24 \mathrm{~h}$, using an inverted fluorescence microscope. (C and D) Phase contrast and fluorescent image cells. Virus-transducted A-1321N1 cells following puromycin selection. Expression of the GFP as a reporter gene was visualized by fluorescent microscopy. GFP, green fluorescent protein.

line or the empty vector (EV) control cells. Subsequently, $5 \mu 1$ of extracted miRNA was adjusted to contain no less than $5 \mu \mathrm{g}$ total miRNA and added to $1.5 \mu \mathrm{l}$ stem-loop RT primer $(50 \mathrm{nM})$ and $4 \mu \mathrm{l}$ distilled water. Reaction samples (10.5 $\mu \mathrm{l})$ were incubated in a Bio-Rad thermal cycler (MJ Mini; Bio-Rad, Hercules, CA, USA) at $65^{\circ} \mathrm{C}$ for $10 \mathrm{~min}$. The samples were kept on ice and $4 \mu 15 \mathrm{X}$ reverse transcriptase buffer (Roche Diagnostics GmbH, Mannheim, Germany), $2 \mu \mathrm{ldNTPs}(10 \mathrm{mM}), 2 \mu \mathrm{l}$ DTT $(10 \mathrm{mM}), 1 \mu \mathrm{l}$ Expand reverse transcriptase (50 units; Roche Diagnostics $\mathrm{GmbH}$ ) and $0.5 \mu \mathrm{l}$ RNase inhibitor (20 units) was added. cDNA synthesis was conducted as follows: $25^{\circ} \mathrm{C}$ for $15 \mathrm{~min}, 37^{\circ} \mathrm{C}$ for $15 \mathrm{~min}$, $42^{\circ} \mathrm{C}$ for $40 \mathrm{~min}$ and finally $95^{\circ} \mathrm{C}$ for $2 \mathrm{~min}$ to inactivate the enzyme.

RT-qPCR was performed in a $12.5 \mu 1$ PCR mixture volume composed of $6.5 \mu \mathrm{l} 2 \mathrm{X}$ Maxima ${ }^{\circledR}$ Probe qPCR master mix (Fermentas, Vilnius, Lithuania), $0.2 \mu \mathrm{M}$ of each oligonucle- otide primer, $0.1 \mu \mathrm{M}$ probe and $2 \mu \mathrm{l}$ cDNA. The following conditions were used for amplification: Enzyme activation step at $95^{\circ} \mathrm{C}$ for $10 \mathrm{~min}$ and 45 cycles of two thermal amplification steps: $94^{\circ} \mathrm{C}$ for $10 \mathrm{sec}$ and $60^{\circ} \mathrm{C}$ for $40 \mathrm{sec}$. Single fluorescence detection was used in each cycle at the end of the $60^{\circ} \mathrm{C}$ step (extension phase) to elucidate the positive samples. The specificity was confirmed using gel electrophoresis. Reactions were set up manually. Amplification, data acquisition and analysis were performed on the Rotor-Gene 6000 (Corbett Life Science) using Rotor-Gene 6.1 and REST software. Samples were assessed in triplicate along with pertaining controls, including positive, negative, no-template and RT-minus controls. A previously approved and non-treated RNA, SNORD 47, was used as an internal control (21). The $\mathrm{Ct}$ is the fractional cycle number at which the fluorescence passes the fixed threshold. REST software was used for statistical analysis of relative miRNA expression. 
Western blot analysis. Total cell lysates were prepared following harvesting cells in ice-cold phosphate-buffered saline (Gibco-BRL) and homogenization in cold lysis buffer (RIPA buffer; Gibco-BRL). Protease inhibitor cocktails (cat no. S8820; Sigma-Aldrich) were added to the lysis buffer. Lysates were centrifuged at $13,680 \mathrm{x}$ g for $10 \mathrm{~min}$ and the supernatant was transferred to a new tube. Protein content was measured using the bicinchoninic acid method (BCA protein kit; Pierce Biotechnology, Inc.). Subsequently, equal quantities of protein $(25 \mu \mathrm{g})$ were added to each well in $12.5 \%$ standard SDS-PAGE and a wet transfer was performed (Bio-Rad). Proteins were transferred onto polyvinylidene difluoride membranes (Gibco-BRL) and membranes were blocked with $2 \%$ skimmed milk in Tris-buffered saline/Tween 20 (TBST 20; 0.5\%; Gibco-BRL) for $2 \mathrm{~h}$ at room temperature. Membranes were incubated overnight at $4^{\circ} \mathrm{C}$ with primary antibodies against Cx43 1:5,000 diluted in TBST (0.5\%). Membranes were washed three times with TBST 20 and subsequently incubated for $1 \mathrm{~h}$ at room temperature with the corresponding horseradish-peroxidase-conjugated secondary antibodies: Rabbit polyclonal secondary antibody to mouse IgG. Following three washes with TBST 20 (0.5\%), detection was conducted by applying Pierce ECL plus western blotting substrate (cat no. 32134; Pierce Biotechnology, Inc.), emanating chemiluminescence from the membrane for manual x-ray film development. Levels of the analyzed proteins were normalized to $\beta$-actin levels.

3-(4,5-dimethylthiazol-2-yl)-2,5-diphenyltetrazolium bromide (MTT) assay. To evaluate the cytotoxic effect of Cln treatment on the A-1321N1 cell line, cell viability was measured using the MTT colorimetric assay (Sigma-Aldrich). Cells were seeded into 96 well plates at a density of $0.5 \times 10^{4}$ cells/well and left overnight to attach. The following day, the medium was changed to a fresh medium containing different concentrations of $\mathrm{Cln}(1,5,10,20$ and $40 \mu \mathrm{g} / \mathrm{ml})$. At $24 \mathrm{~h}$ after treatment, MTT reagent $(5 \mathrm{mg} / \mathrm{ml})$ was added and incubation was continued at $37^{\circ} \mathrm{C}$ for $3 \mathrm{~h}$. The medium was discarded and the formazan crystals were dissolved by adding dimethyl sulfoxide (100 $\mu 1 /$ well; Gibco-BRL). Finally, the optical density of each well was determined using a spectrophotometer (ELx800; BioTek Instruments, Inc., Winooski, VT, USA) at a wavelength of $570 \mathrm{~nm}$ against $630 \mathrm{~nm}$.

Statistical analysis. The acquired data were analyzed by SPSS software 19 (SPSS, Inc., Chicago, IL, USA). P<0.05 was considered to indicate a statistically significant difference. Experiments were performed in triplicate and data are presented as the mean \pm standard error of the means.

\section{Results}

Expression of $C x 43$ by $\beta 2-A R$ signaling agents. The specificity of cAMP signaling on $\mathrm{Cx} 43$ expression in astrocytoma cells was assessed following $24 \mathrm{~h}$ treatment of cells with drugs. Cln $(10 \mu \mathrm{g} / \mathrm{ml})$, a selective $\beta 2$-AR agonist, led to a significant upregulation in $\mathrm{Cx} 43$ at the mRNA (Fig. $2 ; \mathrm{P}<0.001$ ) and protein levels (Fig. 3; $\mathrm{P}<0.05$ ). Pretreatment with $\mathrm{SQ}(50 \mu \mathrm{g} / \mathrm{ml}) 45 \mathrm{~min}$ prior to Cln treatment significantly inhibited $\mathrm{Cx} 43$ expression at the mRNA (Fig. 2; P<0.001) and protein levels (Fig. 3;

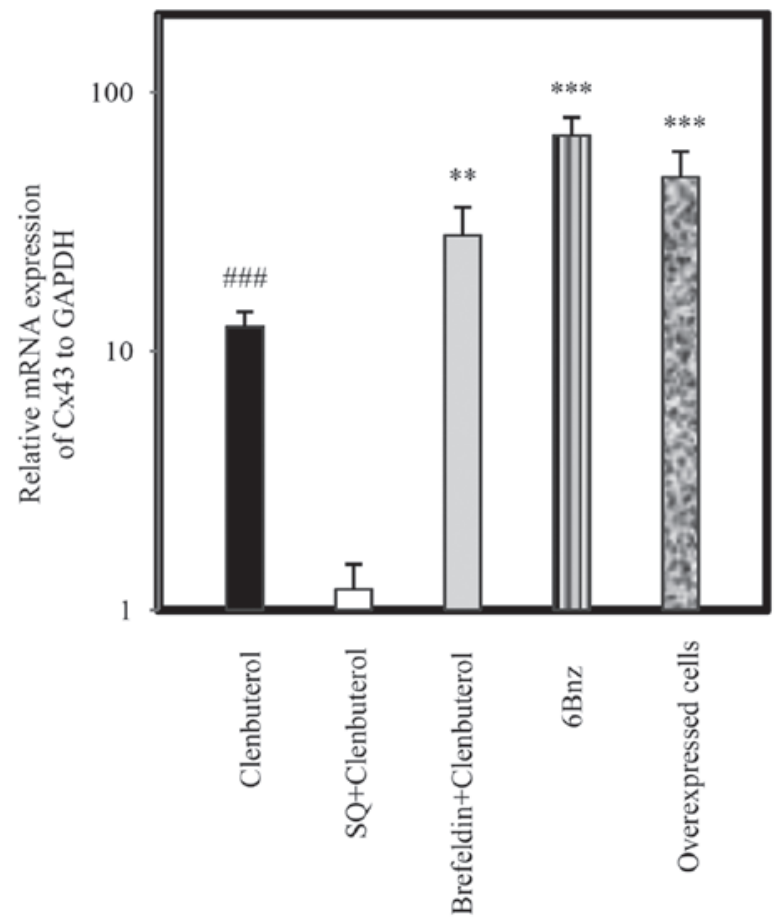

Figure 2. Relative mRNA expression of Cx43 in A-1321N1 cells. A-1321N1 cells were treated with Cln $(10 \mu \mathrm{g} / \mathrm{ml})$, a selective $\beta 2$ agonist; SQ $(50 \mu \mathrm{g} / \mathrm{ml})$, an adenyl cyclase inhibitor + Cln $(10 \mu \mathrm{g} / \mathrm{ml})$; BF $(50 \mu \mathrm{g} / \mathrm{ml})$, an Epac inhibitor $+\mathrm{Cln}$ and $6 \mathrm{Bnz}(50 \mu \mathrm{g} / \mathrm{ml})$, a protein kinase A activator for $24 \mathrm{~h}$ and the relative mRNA expression of $\mathrm{Cx} 43$ was measured. $\mathrm{Cx} 43$ was measured in miR-146a overexpressing A-1321N1 cells. The results revealed that $\mathrm{Cx} 43$ was significantly upregulated following treatment with Cln $(10 \mu \mathrm{g} / \mathrm{ml}), \mathrm{BF}$ $(100 \mu \mathrm{g} / \mathrm{ml})+\mathrm{Cln}(10 \mu \mathrm{g} / \mathrm{ml})$ and 6Bnz $(100 \mu \mathrm{g} / \mathrm{ml})$ in miR-146a overexpressing cells. Pretreatment with SQ $(50 \mu \mathrm{g} / \mathrm{ml})$ completely inhibited Cx43 expression compared with the Cln group, however, Epac inhibition by BF $(100 \mu \mathrm{g} / \mathrm{ml})$ increased its expression. Relative expression of each group was normalized with GAPDH using a relative expression software tool. Data obtained from three independent experiments were analyzed similarly to the control group. Bar graphs show the mean \pm standard error of the mean from at least three individual experiments. ${ }^{* *} \mathrm{P}<0.01,{ }^{* * *} \mathrm{P}<0.001$ and

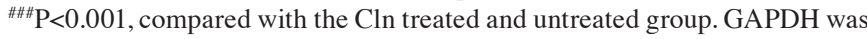
used as a control. $\mathrm{Cx} 43$, connexin 43; Cln, clenbuterol hydrochloride; $6 \mathrm{Bnz}$, 6-Bnz-cAMP sodium salt; BF, Brefeldin; SQ, SQ22,536.

$\mathrm{P}<0.05)$. By contrast, BF $(100 \mu \mathrm{g} / \mathrm{ml})$ administered $45 \mathrm{~min}$ prior to $\mathrm{Cln}$ treatment increased $\mathrm{Cx} 43$ expression at the mRNA (Fig. 2; $\mathrm{P}<0.001$ ) and protein level (Fig. 3; P<0.05) compared with the Cln alone group. Selective activation of PKA by $6 \mathrm{Bnz}$ $(50 \mu \mathrm{g} / \mathrm{ml})$ also resulted in significant upregulation of $\mathrm{Cx} 43$ at the mRNA (Fig. 2) and protein (Fig. 3) level ( $\mathrm{P}<0.001)$. The expression level of $\mathrm{Cx} 43 \mathrm{mRNA}$ was measured in miR-146a overexpressing A-1321N1 cells $(\mathrm{P}<0.001)$. The results revealed that $\mathrm{Cx} 43$ was significantly upregulated (Fig. $2 ; \mathrm{P}<0.001$ ) in a parallel manner to $6 \mathrm{Bnz}$ treatment. Therefore, $\mathrm{Cln}$ may upregulate $\mathrm{Cx} 43$ via PKA activation since 6Bnz, a PKA activator, upregulated $\mathrm{Cx} 43$ expression significantly more than $\mathrm{Cln}$ and Epac inhibition did not prevent its upregulation.

Expression of CREB. CREB level was measured following treatment with different doses of Cln $(10 \mu \mathrm{g} / \mathrm{ml})$ and pre-inhibition with SQ $(50 \mu \mathrm{g} / \mathrm{ml}), \mathrm{ACi}$ and BF $(100 \mu \mathrm{g} / \mathrm{ml})$. Cln treatment upregulated CREB levels, while adenyl cyclase $(\mathrm{P}<0.01)$ and Epac inhibition $(\mathrm{P}<0.05)$ downregulated CREB levels. CREB levels were measured in the $6 \mathrm{Bnz}$ 


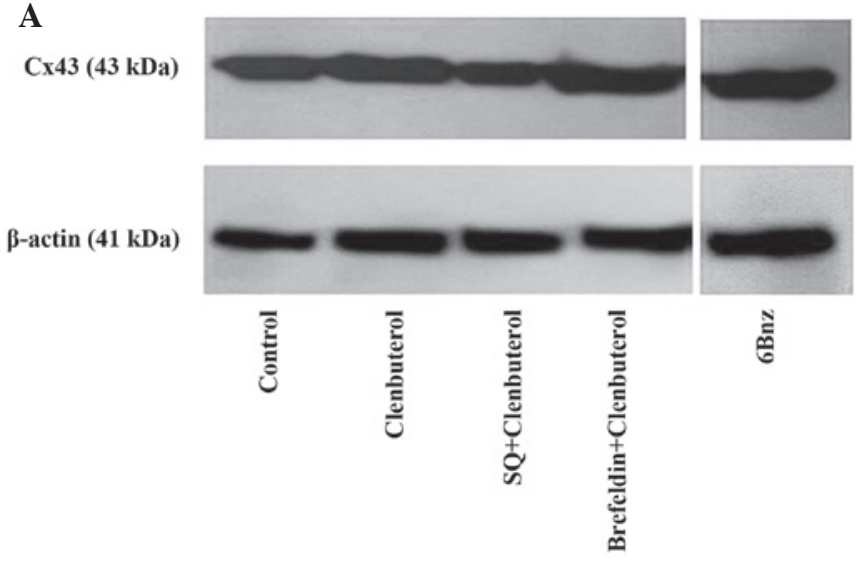

B

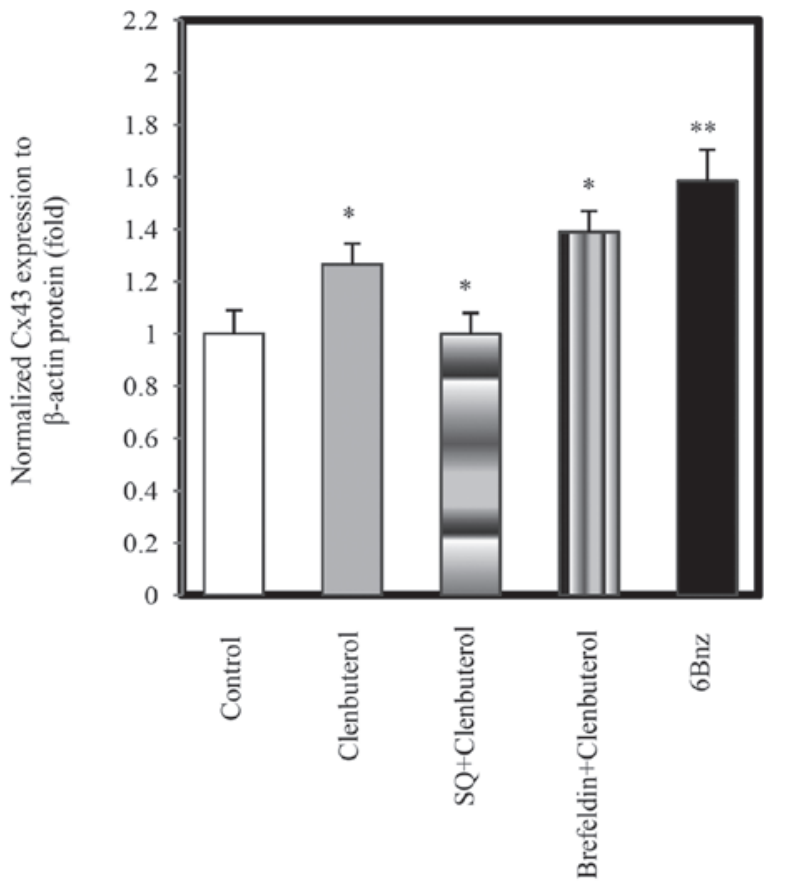

Figure 3. Western blotting of the $\mathrm{Cx} 43$ protein. The bar graph presents the expression level of $\mathrm{Cx} 43$ protein following treatment with $\mathrm{Cln}$ and the cAMP/protein kinase A-Epac signaling pathway in A-1321N1 cells. (A) Expression of $\mathrm{Cx} 43$ protein in A-1321N1 cells. Cx43 protein level was normalized to $\beta$-actin. (B) Bar graphs show the mean \pm standard error of the mean from at least three individual experiments. Cln $(10 \mu \mathrm{g} / \mathrm{ml}), \mathrm{BF}$ $(100 \mu \mathrm{g} / \mathrm{ml})+\mathrm{Cln}$ and $6 \mathrm{Bnz}(100 \mu \mathrm{g} / \mathrm{ml})$ significantly increased $\mathrm{Cx}_{4} 43$ expression compared with the control group. SQ $50 \mu \mathrm{g} / \mathrm{ml}$ significantly downregulated $\mathrm{Cx} 43$ expression compared with the Cln group. ${ }^{\mathrm{P}} \mathrm{P}<0.05$ and ${ }^{* *} \mathrm{P}<0.01$, compared with the control group. Blots from one representative experiment are shown. $\mathrm{Cx} 43$, connexin 43; Cln, clenbuterol hydrochloride; 6Bnz, 6-Bnz-cAMP sodium salt; BF, Brefeldin; SQ, SQ 22,536.

(50 $\mu \mathrm{g} / \mathrm{ml})$-treated group, which significantly upregulated the level of CREB $(\mathrm{P}<0.001)$. Epac inhibition decreased CREB level compared with the $\mathrm{Cln}(\mathrm{P}<0.05)$ and $6 \mathrm{Bnz}$ $(\mathrm{P}<0.001)$ groups, however, its higher expression compared with the adenyl cyclase inhibited group was not significant. Expression of CREB in miR-146a overexpressing A-1321N1 cells was measured and the results shown in Fig. 4 demonstrated that its expression significantly increased compared with GAPDH $(\mathrm{P}<0.001)$.

Additionally, the mRNA level of Cx43 and CREB in miR-146a overexpressing A-1321N1 cells $(\mathrm{P}<0.001)$ was measured, which demonstrated that $\mathrm{Cx} 43$ and $\mathrm{CREB}$ were

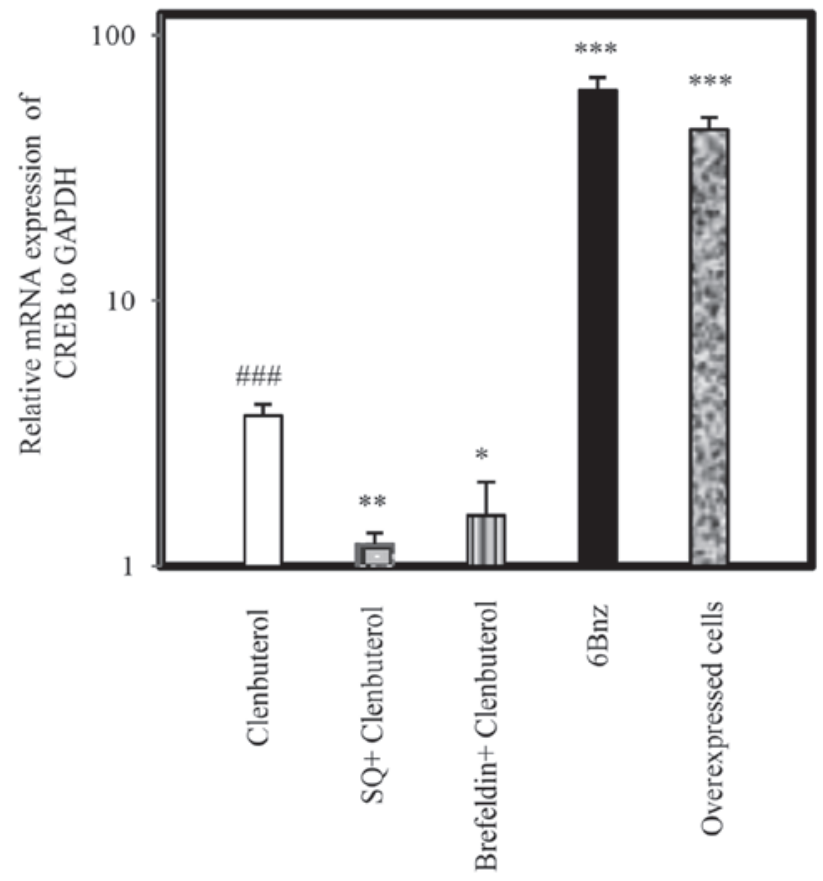

Figure 4. Relative mRNA expression of CREB in A-1321N1 cells. This figure presents the relative mRNA expression of CREB in the $\beta 2$-adrenergic receptor signaling pathway. Cln $(10 \mu \mathrm{g} / \mathrm{ml})$ treatment significantly upregulated the mRNA level of CREB compared with GAPDH expression. SQ $(50 \mu \mathrm{g} / \mathrm{ml})$ and Brefeldin $(100 \mu \mathrm{g} / \mathrm{ml})$ significantly pre-inhibited Cln treatment of CREB expression. 6Bnz $(50 \mu \mathrm{g} / \mathrm{ml})$ and the miR-146a overexpressed cell group had significantly increased levels of CREB mRNA compared with the Cln group. Data obtained from three independent experiments were analyzed similarly to the control group. Bar graphs show the mean \pm standard error of the mean from at least three individual experiments. Different treatment groups compared with the Cln group and Cln compared with the untreated group. ${ }^{*} \mathrm{P}<0.05,{ }^{* *} \mathrm{P}<0.01,{ }^{* * *} \mathrm{P}<0.001$ and ${ }^{\# \# \#} \mathrm{P}<0.001$, compared with the $\mathrm{Cln}$ treated and untreated group. GAPDH was used as a control. Cln, clenbuterol hydrochloride; CREB, cAMP response element-binding protein; SQ, SQ 22,536; 6Bnz, 6-Bnz-cAMP sodium salt.

significantly upregulated in a parallel manner in miR-146a overexpressing cells (Fig. 5; $\mathrm{P}<0.001$ ).

Effects of $\beta 2-A R, P K A$ and Epac activation on miRNA level. Fig. 6 shows the miR-146a level in overexpressing astrocytoma cells and EV of A-1321N1 cells. miR-146a was significantly upregulated in overexpressing A-1321N1 cells compared with EV cells $(\mathrm{P}<0.001)$.

Putative regulation of miR-146a was verified by stem-loop RT-qPCR after $24 \mathrm{~h}$ treatment. Pharmacological intervention of the cAMP/PKA pathway with different drugs demonstrated that $\mathrm{Cln}$ at doses of 10 and $20 \mu \mathrm{g} / \mathrm{ml}$ significantly upregulated miR-146a level in A-1321N1 cells $(\mathrm{P}<0.001)$. 6Bnz $(50 \mu \mathrm{g} / \mathrm{ml})$, a PKA activator, had the same effect as $\mathrm{Cln}(\mathrm{P}<0.001)$. However, 8CPT, an Epac activator, $(50 \mu \mathrm{g} / \mathrm{ml})$ downregulated the level of miR-146a $(\mathrm{P}<0.001)$. Adenyl cyclase $(20 \mu \mathrm{g} / \mathrm{ml})$ inhibition eliminated the effect of Cln (10 and $20 \mu \mathrm{g} / \mathrm{ml})$ on miR-146a expression at the two doses $(\mathrm{P}<0.01)$. Taken together, the results suggested that miR-146a expression was upregulated through the cAMP/PKA pathway and was decreased via the cAMP-Epac pathways (Fig. 7).

Fig. 8 illustrates pharmacological intervention on miR-146a and two oncomiRs, miR-155 and miR-27a. Cln (10 $\mu \mathrm{g} / \mathrm{ml})$ and 6Bnz $(50 \mu \mathrm{g} / \mathrm{ml})$ significantly upregulated miR-146a levels, 


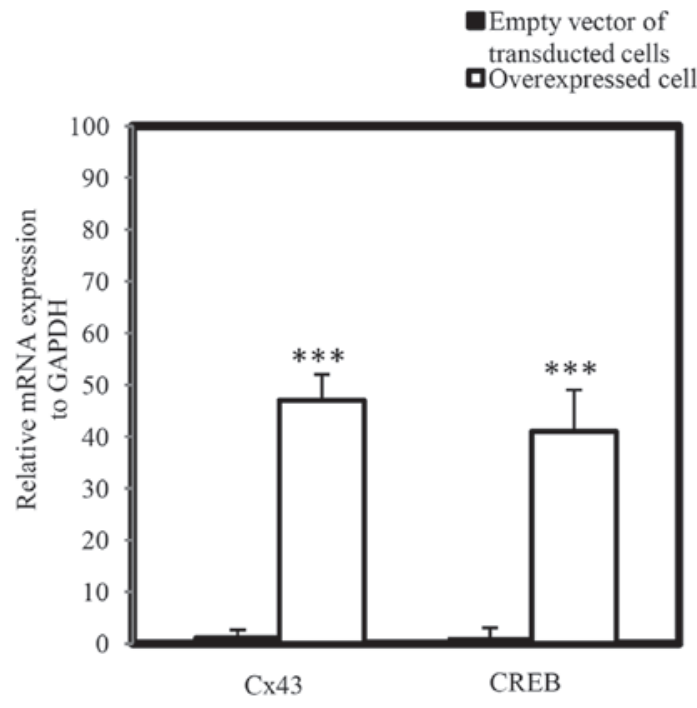

Figure 5. Relative mRNA expression of $\mathrm{Cx} 43$ and CREB in A-1321N1 cells and overexpressed miR-146a in A-1321N1 cells. The figure presents the mRNA level of Cx43 and CREB in astrocytoma 1321N1 cells and overexpressing miR-146a $1321 \mathrm{~N} 1$ astrocytoma cells. Cx43 and CREB expression significantly increased their expression in a parallel manner compared with GAPDH. ${ }^{* * *} \mathrm{P}<0.001$, compared with $\mathrm{Cx} 43$ and CREB expression in the A-1321N1 cells, which overexpress miR-146a. Cx43, connexin 43; CREB, cAMP response element-binding protein.

while the level of miR-155 was significantly downregulated. Treatment with Cln $(10 \mu \mathrm{g} / \mathrm{ml})$ and $6 \mathrm{Bnz}(50 \mu \mathrm{g} / \mathrm{ml})$ also downregulated miR-27a, however, this was not significant. Following treatment with the Epac activator, $8 \mathrm{CPT}(20 \mu \mathrm{g} / \mathrm{ml})$, the levels of miR-155 and miR-27a were upregulated, while the levels of miR-146a were significantly downregulated. By contrast, $6 \mathrm{Bnz}(50 \mu \mathrm{g} / \mathrm{ml})$ significantly upregulated the level of miR-146a. Therefore, $\beta 2$-AR stimulation and PKA activation increased the suppressant miR-146a levels and decreased the level of miR-155 and miR-27a oncomiRs, while Epac activation downregulated miR-146a and upregulated oncomiRs, miR-155 and miR-27a.

Cell viability. Different doses of Cln (1, 5, 10, 20 and $40 \mu \mathrm{g})$ inhibited cell proliferation in a dose-dependent manner (Fig. 9). Cln significantly inhibited cell proliferation after 24 and $48 \mathrm{~h}$ compared with the control group.

Expression of Connexin 43 and miRNAs via $\beta 2$ adrenoceptor signaling in A-1321N1cell. $\beta 2$ adrenoceptor activation via cAMP-PKA pathway upregulated the expression levels of Cx43, CREB and miR-146a and downregulated the expression of miR-155. By contrast, the $\beta 2$ adrenoceptor upregulated the expression levels of miR-27a and miR-155, and downregulated the expression of miR-146a via the cAMP-Epac pathway (Fig. 10).

\section{Discussion}

Currently, molecular target therapy has become one of the most useful strategies for disease treatment (22) and may be a promising approach for astrocytoma and glioma therapy (23). The findings in the present study exhibit novel $\mathrm{Cx} 43$ regulation in astrocyte models, that were demonstrated by overexpression

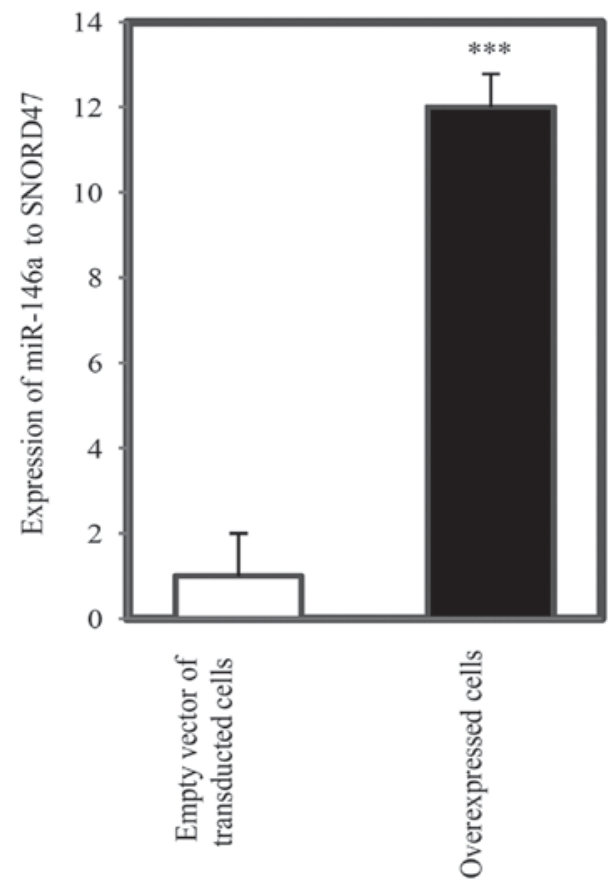

Figure 6. miR-146a expression. Expression level of miR-146a in overexpressed cells was significantly enhanced compared with empty vector-transduced astrocytoma $1321 \mathrm{~N} 1$ cells. ${ }^{* * *} \mathrm{P}<0.001$, compared with te empty vector-transduced astrocytoma 1321N1 cells. Expression level was normalized with SNORD47.

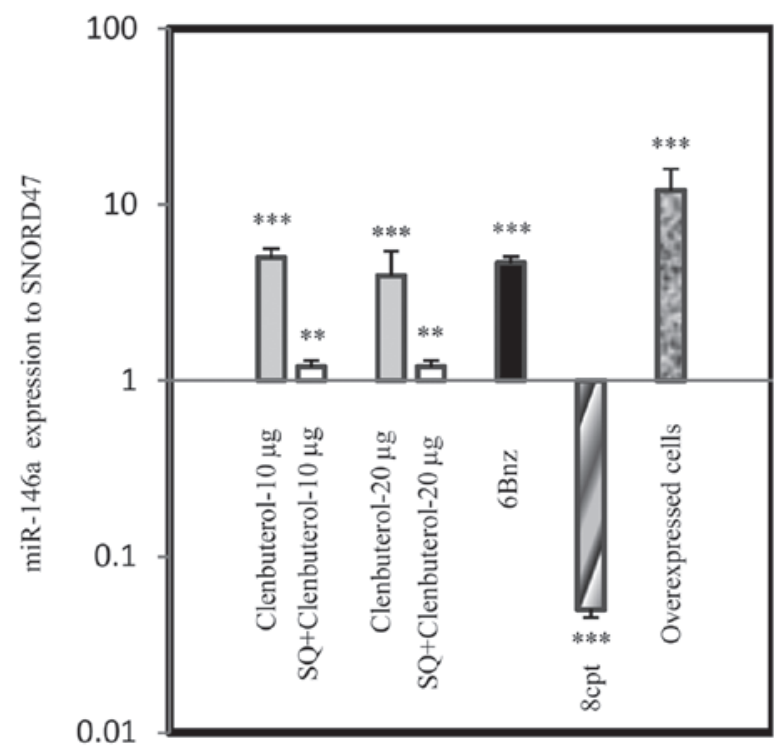

Figure 7. miR-146a expression via $\beta 2$-AR signaling. $\beta 2$-AR signaling intervention modulated the relative expression of miR-146a level in astrocytoma 1321N1. Cln at doses of 10 and $20 \mu \mathrm{g} / \mathrm{ml}$ increased miR-146a level and the adenyl cyclase inhibitor, SQ $(50 \mu \mathrm{g} / \mathrm{ml})$, significantly suppressed Cln treatment. 6Bnz (100 $\mu \mathrm{g} / \mathrm{ml}$; protein kinase A activator) and 8CPT $(50 \mu \mathrm{g} / \mathrm{ml})$, an Epac activator, significantly increased and decreased miR-146a expression, respectively. Overexpressed miR-146a cells exhibited increased miR-146a levels compared with all groups and SNORD47. ${ }^{* *} \mathrm{P}<0.01$ and ${ }^{* * *} \mathrm{P}<0.001$, compared with the untreated cells. Data were normalized to the SNORD47, housekeeping gene. $\mathrm{Cln}$, clenbuterol hydrochloride; $\beta 2$-AR, $\beta 2$-adrenergic receptor; SQ, SQ 22,536; 6Bnz, 6-Bnz-cAMP sodium salt; $8 \mathrm{CPT}$, 8-(4-chlorophenylthio)-2'-O-methyladenosine-3',5'-cyclic monophosphate.

of miR-146a in the A-1321N1 cell line and $32-A R$ stimulation in A-1321N1 cells. These results revealed that $\beta 2-A R$ 


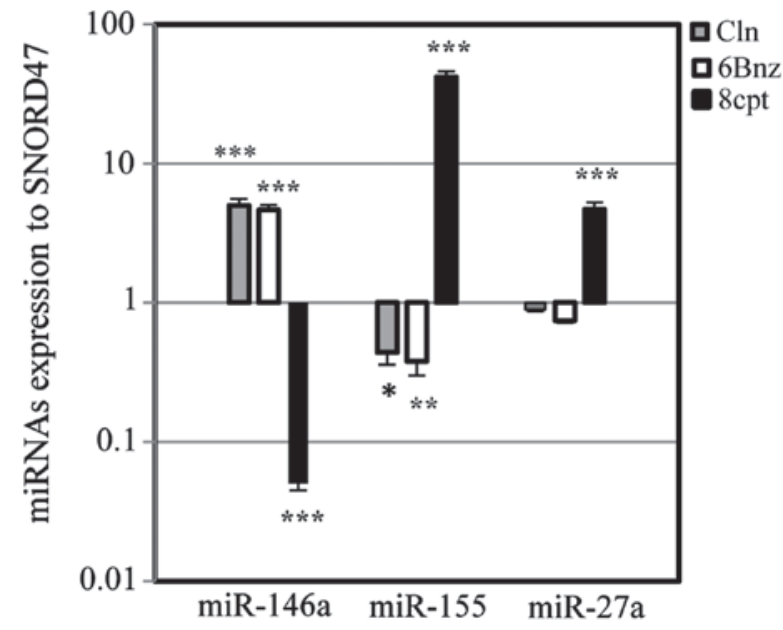

Figure 8. miRNA expression via protein kinase A and Epac activation. The effect of Cln, 6Bnz and 8CPT treatment on the levels of miR-146a, miR-155 and miR-27a in $1321 \mathrm{~N} 1$ astrocytoma cells. Cln $(10 \mu \mathrm{g} / \mathrm{ml})$ and 6Bnz $(50 \mu \mathrm{g} / \mathrm{ml})$ increased miR-146a and decreased miR-155 significantly in addition to miR-27a (not significant), however, 8CPT $(20 \mu \mathrm{g} / \mathrm{ml})$ decreased miR-146a and increased miR-155 and miR-27a significantly. Data were normalized to SNORD47, a housekeeping miRNA. ${ }^{*} \mathrm{P}<0.05,{ }^{* * *} \mathrm{P}<0.01$ and ${ }^{* * * *} \mathrm{P}<0.001$, compared with the untreated cells. Cln, clenbuterol hydrochloride; 6Bnz, 6-Bnz-cAMP sodium salt; 8CPT, 8-(4-chlorophenylthio)-2'-O-methyladenosine-3',5'-cyclic monophosphate.

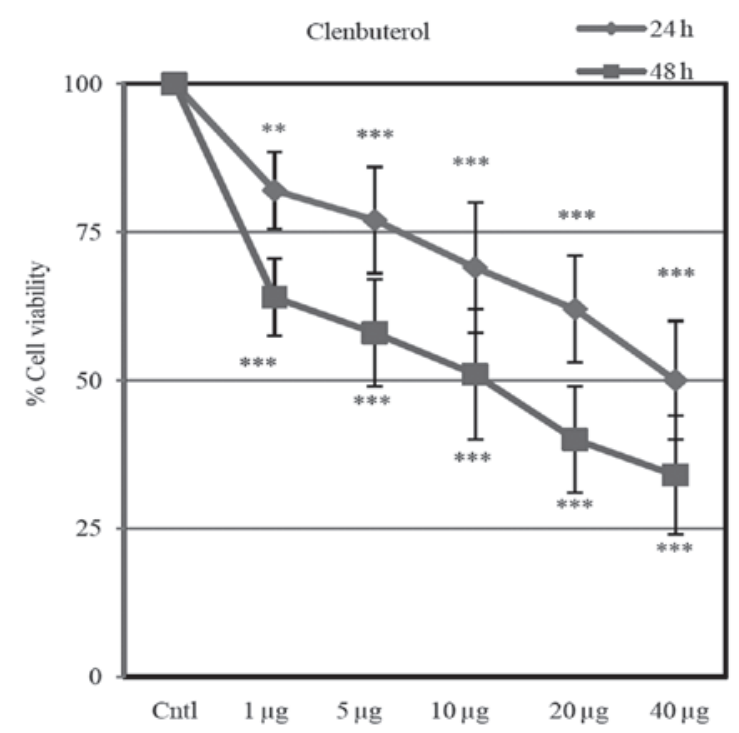

Figure 9. Cell viability assessment. Clenbuterol decreased the cell viability of A-1321N1 cells in a dose-dependent manner. Different doses of Clenbuterol (1, $5,10,20$ and $40 \mu \mathrm{g}$ ) inhibited cell proliferation dose dependently. Clenbuterol (40 $\mu \mathrm{g} / \mathrm{ml})$ significantly inhibited the cell viability of $1321 \mathrm{~N} 1$ astrocytoma (24 and $48 \mathrm{~h}$ ) compared with the control groups $\left({ }^{* *} \mathrm{P}<0.01 ;{ }^{* * *} \mathrm{P}<0.001\right)$

activation upregulates the expression of $\mathrm{Cx} 43$ in astrocytes via a PKA-regulated pathway, possibly involving CREB. In this regard, the overexpression of miR-146a is also able to cause upregulation of CREB and Cx43 in this cell line, in which miR-146a was upregulated by PKA activation. Furthermore, $\beta 2-A R$ adrenoceptor signaling activation decreases the severity of the glioma as well as decreases the promotion of molecules, including miR-155 (24-27) and miR-27a $(28,29)$ via its signaling pathway. PKA, activated by $6 \mathrm{Bnz}$, acts as a suppressor of the astrocytoma signaling pathway and glioma while the Epac signaling pathway, activated by $8 \mathrm{CPT}$ acts as a modulator. Therefore, $\beta 2$-AR signaling and particularly PKA activation may be useful strategies for astrocytoma and glioma therapy. Despite considerable advances in miRNA research, there are various obstacles for the use of miRNAs in clinics, including miRNA delivery, which prevents the use of miRNAs as drugs. Therefore, the drugs that may activate PKA or $\beta 2-A R$ signaling have modulating potential on miRNA delivery in astrocytoma and $\mathrm{Cx} 43$ expression.

In the present study, the effects of $\beta 2$-AR signaling on $\mathrm{Cx} 43$ expression and its modulating effect on miR-146a level were evaluated. In addition, the effects of high levels of miR-146a on Cx43 expression were assessed by overexpressing miR-146a in A-1321N1 cells. In further investigations, the activation of $\beta 2-A R$ signaling was evaluated and the mechanism by which PKA and Epac downstream pathways affected the two oncomiRs, miR-155 and miR-27a was assessed. The expression of CREB, a pathway downstream of PKA, in A-1321N1 cells overexpressing miR-146a and standard A-1321N1 cells was also evaluated, which were subject to pharmacological intervention. These evaluations revealed that CREB level increased in miR-146a overexpressing cells and in cells treated with Cln and 6Bnz.

Since the aim of the present study was to demonstrate the effects of $\beta 2-\mathrm{AR}$ signaling on $\mathrm{Cx} 43$ and miR-146a, the A-1321N1 cell line, which is a high grade astrocytoma model, appropriate for signaling studies was utilized (30). miRNA detection was based on the stem-loop method, which is recognized for producing high quality data. The current results present a method for enhancing the level of miR-146a and $\mathrm{Cx} 43$ in the astrocytoma cell line via PKA activation and 32-AR stimulation.

Higher grade human brain tumors are associated with lower adenyl cyclase activity and/or cellular cAMP levels (31), in which signaling is modulated by the $\beta 2-A R$ signaling pathway (1). cAMP and its associated downstream pathways, including 8-Chloro cAMP (17) and PKA (18) have been observed to inhibit the proliferation of tumor cells $(20,23)$. Additionally, $\beta 2-A R$ knockout astrocytes exhibited higher proliferation rates compared with wild-type cells (32). Increasing the level of adenyl cyclase activity has been associated with decreased glioma cell proliferation (31). By contrast, Somekawa et al (16) demonstrated that PKA activation predominantly contributes to the functional neoformation of gap junctions and that Epac is also responsible for gap junction neoformation. In cultured astrocytes, Salameh et al (33) demonstrated that PKA and mitogen-activated protein kinase are involved in $\mathrm{Cx} 43$ expression via activator protein 1 and CREB through $\beta 2-A R$ stimulation. Lu et al (34) demonstrated that $\beta 2$-AR blockers decreased miR-1 level via inhibition of the $\beta 2$-AR-cAMP-PKA pathway in myocytes, which led to downregulation of $\mathrm{Cx} 43$ expression. In the present study, it was observed that $\beta 2-\mathrm{AR}$ stimulation, via activation of PKA downstream pathways, upregulated the expression of Cx43 and CREB as well as miR-146a level in A-1321N1 cells via $\beta 2-A R$ activation. The current results implied that $\beta 2-A R$ activation and PKA stimulation upregulate $\mathrm{Cx} 43$ and $\mathrm{CREB}$ expression. Activation of another $\beta 2-A R$ downstream pathway, Epac, decreased miR-146a level and overexpression of miR-146a had an enhancing effect on 


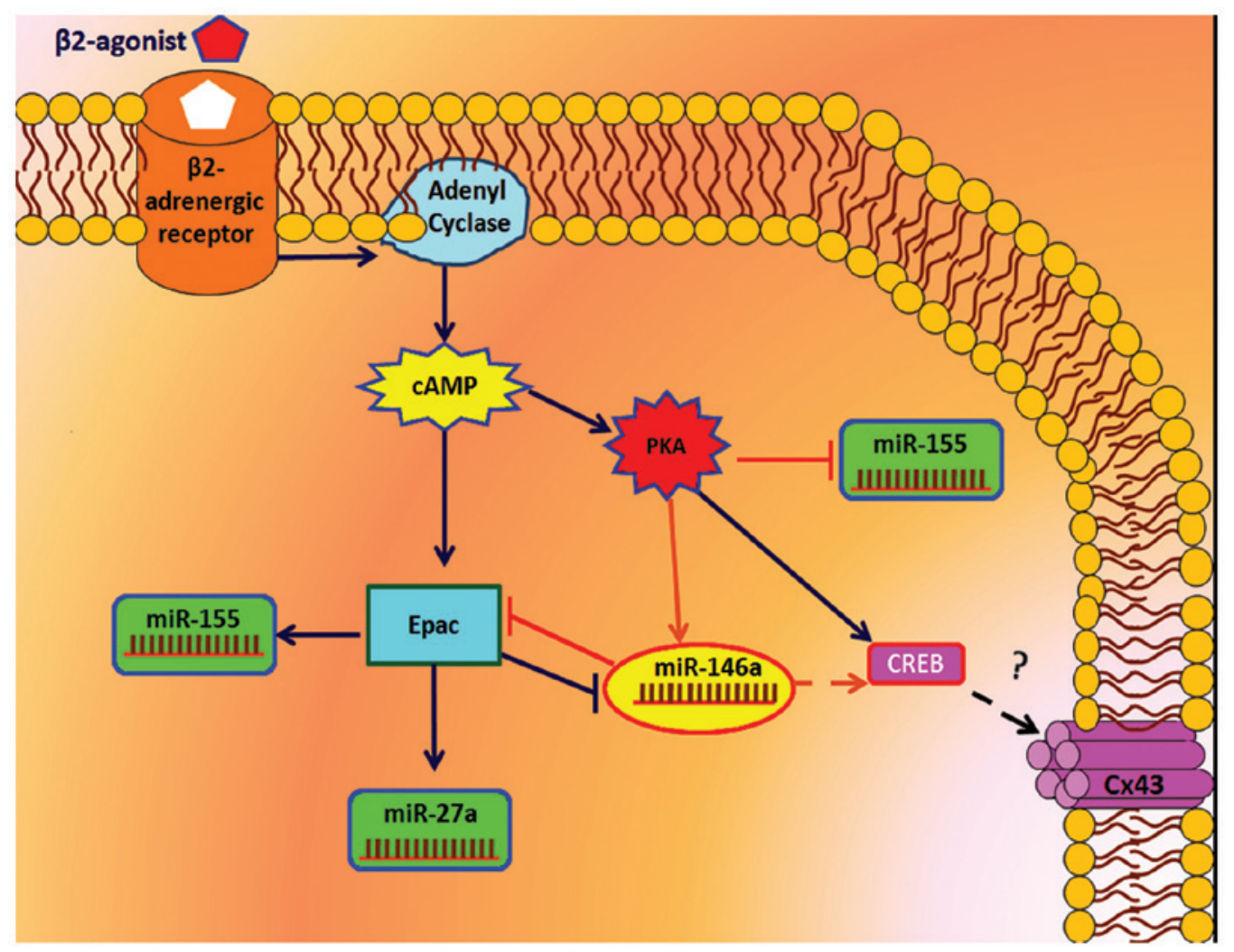

Figure 10. Summary of the expression of connexin 43 and miRNAs via $\beta 2$-adrenoceptor signaling. This figure presents a possible pathway of connexin 43 signaling and tumor-associated miRNA via the $\beta 2$-adrenoceptor signaling pathway in astrocytoma $1321 \mathrm{~N} 1$ cells. The effects of miR-146a on Epac expression were not evaluated experimentally; however, bioinformatics analysis supported this inhibition (unpublished data). Solid arrows indicate stimulatory effects; broken arrows indicate possible stimulatory effects; T-shaped arrows indicate inhibitory effects. CREB, cAMP response element-binding protein; Cx43, connexin 43; PKA, protein kinase A.

Cx43, which was also demonstrated in the present study. This demonstrates that the activation of Epac may negatively effect Cx43 expression. In the present study, Epac was deactivated in order to analyze its effect on Cx43 expression, which as expected, was enhanced. The present study is in accordance with other studies regarding $\mathrm{Cx} 43$ modulation in astrocytes via PKA-CREB activation $(33,35)$. Certain studies have revealed that PKA activation in myocytes had weak (16) or inhibitory effects (36) on Cx43 expression. Although in these studies, miR-1 was investigated in myocytes, which directly targets $\mathrm{Cx} 43$, whereas in the present study, the microRNA investigated (miR-146a) had an indirect role in the upregulation of $\mathrm{Cx} 43$ in the A-1321N1 cell line.

Epidermal growth factor (EGF) signals and their downstream phosphatidylinositide 3-kinase (PI3K)-Akt pathways are established as astrocytoma and glioma promoting pathways $(18,23,37)$. Receptor tyrosine kinases (RTKs) also possess roles in activation of these pathways (23). Our bioinformatics evaluation demonstrated that miR-146a targets Epidermal growth factor receptor (EGFR) and RTK signaling (unpublished data). In addition, miR-146b inhibits EGFR expression and decreases in vitro invasion and migration of astrocytoma and glioma cell lines (38). By contrast, there is a significant link between the overexpression of EGFR and Cx43 downregulation. In rat cortical astrocytes, Cx43 was downregulated by EGF signaling stimulation (39). In addition, in the present study, it was demonstrated that $\beta 2$-AR stimulation or PKA activation upregulates miR-146a; therefore, it is possible that miR-146a induced the downregulation of $\mathrm{Cx} 43$ via targeting EGFR pathways.

Expression of Cx43 enhanced tumor suppressant function (37) and anti-proliferative effects on astrocytoma cells. Cx43 upregulation and PI3K-Akt pathway inhibition was able to modulate the proliferation of astrocytoma cells $(38,39)$. Upregulation of miR-155 directly targets Foxo3a (24), which inhibits cell-cycle progression at the G1/S transition via regulating transcription of the cyclin-dependent kinase inhibitor p27 (Kip1), which is recurrently downregulated in human glioma (40). In astrocytoma and glioma cells, the level of miR-155 is higher than normal, which is known to be an oncomiR in glioma development $(24,41)$. Thus, downregulation of miR-155 was able to decrease its inhibitory effect on Foxo3a and consequently, Foxo3a inhibits the PI3K-Akt pathway and its proliferative effects. It is evident that Epac activation may have an opposite role since it was revealed in the present study that it downregulates miR-146a and upregulates miR-155 levels. Since miR-27a downregulation via $\beta 2$-AR signaling and the PKA pathway was not significant, this suggests that it is not important in A-1321N1 cells. miR-155 is elevated in primary and secondary glioblastoma and promotes glioma development (41). It has been established as one of the prognostic and predictive markers in glioblastoma patients (42). The present results indicated that Cln and PKA activation decreased miR-155 level and Epac activation increased its level. Thus, PKA downregulates miR-155 and acts as a tumor suppressant pathway, while Epac increases 
miR-155 as a tumor inducer pathway. miR-27a is an oncogenic and multidrug resistant miRNA overexpressed in glioma, which promotes cell proliferation (28). This microRNA is predicted to be involved in glioma progression and initiation via different signaling pathways, including adherens junction, focal adhesion, the mitogen-activated protein kinase signaling pathway, the p53 signaling pathway and the apoptotic signaling pathway (29). miR-27a is upregulated by Epac activation, however, PKA activation downregulates its level, although Cln was not able to significantly alter its levels. miRwalk and miRrecords predicted (unpublished data) that miR-155 and miR-27a targeted CREB expression. In adipocytes, it is validated that CREB was targeted by miR-155 induced by tumor necrosis factor- $\alpha$ (43). The present study revealed that $6 \mathrm{Bnz}$ and Cln increased CREB expression, thus, it is possible that the downregulation of miR-155 via $6 \mathrm{Bnz}$ and $\mathrm{Cln}$ increases CREB levels and Cx43 expression indirectly.

The studies conducted by Toll et al (1) and Johnstone et al (44) support the present results. In these studies, it was suggested that cAMP elevation induced by $\beta 2-\mathrm{AR}$ agonists has a role in antiproliferation and $\mathrm{Cx} 43$ in glioma growth inhibition. Toll et al (1) demonstrated that cAMP-associated inhibition of cell growth in astrocytoma is able to reduce cell growth by preventing the growth factor-mediated cell proliferation signaling pathways; for instance, extracellular-signal-regulated kinase increases the levels of cell-cycle inhibitor proteins p21cip1 and p27kip1 (1). Johnstone et al (44) suggested that enhancement of $\mathrm{Cx} 43$ expression prolonged mitotic periods in order to correspond with a G1 delay in cell cycle, which was associated with an enhancement in the expression of the cell cycle inhibitor p21cip1 in HeLa-43 and HFF cells (44). Huang et al (45) demonstrated that Cx43 acts as a tumor suppressor gene, which reduced cell proliferation in vitro and in vivo in Cx43-transfected glioma cell lines (45). The present study revealed that $\mathrm{Cln}$ upregulates $\mathrm{Cx} 43$ expression and decreases cell viability in a dose-dependent manner and its anti-proliferative effect may be associated with $\mathrm{Cx} 43$ enhancement.

The current results indicated that $\beta 2$-AR signaling via the downstream cAMP-PKA pathway led to enhanced expression of Cx43 and miR-146a in A-1321N1 cells. PKA is the most important downstream pathway with a potential effect on the expression of $\mathrm{Cx} 43$ and miR-146a for the treatment of astrocytoma and glioblastoma. The current findings suggest that the $\beta 2-\mathrm{AR}$ pathway results in the upregulation of $\mathrm{Cx} 43$, CREB and miR-146a via the PKA pathway. By contrast, it was demonstrated that miR-146a overexpression may also result in upregulation of CREB and Cx43. Furthermore, the activation of the PKA pathway caused a downregulation in the expression of the miR-155 oncomiR. This demonstrates the tumor suppressor role of the PKA pathway. However, the Epac pathway decreases the expression of miR-146a, the glioma suppressing microRNA, which also possesses a significant function in the overexpression of $\mathrm{Cx} 43$. The Epac pathway also induces the overexpression of miR-155 and miR-27a oncomiRs. Overall, the PKA pathway decreased tumor-associated features in A-1321N1 cells. These findings not only enhance understanding of certain aspects of the molecular biology of astrocytoma and glioma, but may also clarify views on new prospective therapeutic and drug targets.

\section{Acknowledgements}

This study was supported by The Deputy of Research, Tehran University of Medical Sciences. The authors would like to thank the Stem Cell Technology Research Center (Tehran, Iran) for their support. In addition, they would like to thank Mrs. Fatemeh Kohram and Dr Abolreza Ardeshirylajimi for technical assistance.

\section{References}

1. Toll L, Jimenez L, Waleh $\mathrm{N}$, et al: $\beta 2$-adrenergic receptor agonists inhibit the proliferation of $1321 \mathrm{~N} 1$ astrocytoma cells. J Pharmacol Exp Ther 336: 524-532, 2011.

2. Vinken M, Decrock E, De Vuyst E, et al: Connexins: sensors and regulators of cell cycling. Biochim Biophys Acta 1815: 13-25, 2011.

3. Gabriely G, Yi M, Narayan RS, et al: Human glioma growth is controlled by microRNA-10b. Cancer Res 71: 3563-3572, 2011.

4. Castro MG, Cowen R, Williamson IK, et al: Current and future strategies for the treatment of malignant brain tumors. Pharmacol Ther 98: 71-108, 2003.

5. Lin JH, Takano T, Cotrina ML, et al: Connexin 43 enhances the adhesivity and mediates the invasion of malignant glioma cells. J Neurosci 22: 4302-4311, 2002.

6. Sin WC, Crespin S and Mesnil M: Opposing roles of connexin43 in glioma progression. Biochim Biophys Acta 1818: 2058-2067, 2012.

7. Huang RP, Hossain MZ, Huang R, Gano J, Fan Y and Boynton AL: Connexin 43 (cx43) enhances chemotherapy-induced apoptosis in human glioblastoma cells. Int J Cancer 92: 130-138, 2001.

8. Huang R, Liu YG, Lin Y, Fan Y, Boynton A, Yang D and Huang RP: Enhanced apoptosis under low serum conditions in human glioblastoma cells by connexin 43 (Cx43). Mol Carcinog 32: 128-138, 2001.

9. $\mathrm{Pu} \mathrm{P}, \mathrm{X}$ ia Z, Yu S and Huang Q: Altered expression of Cx43 in astrocytic tumors. Clin Neurol Neurosurg 107: 49-54, 2004.

10. Soroceanu L, Manning Jr TG and Sontheimer, H: Reduced expression of connexin-43 and functional gap junction coupling in human gliomas. Glia 33: 107-117, 2001.

11. Mesnil M: Connexins and cancer. Biol Cell 94: 493-500, 2002.

12. Sánchez-Alvarez R, Paíno T, Herrero-González S, Medina JM and Tabernero A: Tolbutamide reduces glioma cell proliferation by increasing connexin 43 , which promotes the up-regulation of p21 and p27 and subsequent changes in retinoblastoma phosphorylation. Glia 54: 125-134, 2006.

13. Maatouk D and Harfe B: MicroRNAs in development. ScientificWorldJournal 6: 1828-1840, 2006.

14. Novakova J, Slaby O, Vyzula R and Michalek J: MicroRNA involvement in glioblastoma pathogenesis. Biochem Biophys Res Commun 386: 1-5, 2009.

15. Jin Z, Xu S, Yu H, Yang B, Zhao H and Zhao G: miR-125b inhibits Connexin43 and promotes glioma growth. Cell Mol Neurobiol 33: 1143-1148, 2013.

16. Somekawa S, Fukuhara S, Nakaoka Y, Fujita H, Saito Y and Mochizuki N: Enhanced functional gap junction neoformation by protein kinase A-dependent and Epac-dependent signals downstream of cAMP in cardiac myocytes. Circ Res 97: 655-662, 2005.

17. Shu M, Zhou Y, Zhu W, et al: MicroRNA 335 is required for differentiation of malignant glioma cells induced by activation of cAMP/protein kinase A pathway. Mol Pharmacol 81: 292-298, 2012.

18. Mei J, Bachoo R and Zhang CL: MicroRNA-146a inhibits glioma development by targeting Notch1. Mol Cell Biol 31: 3584-3592, 2011.

19. Barde I, Salmon P and Trono D: Production and titration of lentiviral vectors. Curr Protoc Neurosci, 2010, Chapter 4.

20. Chen C, Ridzon DA, Broomer AJ, et al: Real-time quantification of microRNAs by stem-loop RT-PCR. Nucleic Acids Res 33: e179, 2005.

21. Mohammadi-Yeganeh S, Paryan M and Mirab Samiee S: Development of a robust, low cost stem-loop real-time quantification PCR technique for miRNA expression analysis. Mol Biol Rep 40: 3665-3674, 2013.

22. Takano S, Yamashita T and Ohneda O: Molecular therapeutic targets for glioma angiogenesis. J Oncol 2010: 351908, 2010. 
23. Bai RY, Staedtke V and Riggins GJ: Molecular targeting of glioblastoma: Drug discovery and therapies. Trends Mol Med 17: 301-312, 2011.

24. Ling N, Gu J, Lei Z, et al: microRNA-155 regulates cell proliferation and invasion by targeting FOXO3a in glioma. Oncol Rep 30: 2111-2118, 2013.

25. Lages E, Guttin A, El Atifi M, et al: MicroRNA and target protein patterns reveal physiopathological features of glioma subtypes. PLoS One 6: e20600, 2011.

26. Chaudhry MA, Sachdeva $H$ and Omaruddin RA: Radiation-induced micro-RNA modulation in glioblastoma cells differing in DNA-repair pathways. DNA Cell Biol 29: 553-561, 2010.

27. Poltronieri P, D'Urso PI, Mezzolla V and D'Urso OF: Potential of anti-cancer therapy based on anti-miR-155 oligonucleotides in glioma and brain tumours. Chem Biol Drug Des 81: 79-84, 2013.

28. Feng SY, Dong CG, Wu WK, Wang XJ, Qiao J and Shao JF: Lentiviral expression of anti-microRNAs targeting miR-27a inhibits proliferation and invasiveness of U87 glioma cells. Mol Med Rep 6: 275-281, 2012.

29. Yang S, Wang K, Qian C, et al: A predicted miR-27a-mediated network identifies a signature of glioma. Oncol Rep 28: 1249-1256, 2012.

30. Blum AE, Walsh BC and Dubyak GR: Extracellular osmolarity modulates $\mathrm{G}$ protein-coupled receptor-dependent ATP release from 1321N1 astrocytoma cells. Am J Physiol Cell Physiol 298: C386-C396, 2010

31. Racagni G, Pezzotta S, Giordana MT, et al: Cyclic nucleotides in experimental and human brain tumors. J Neurooncol 1: 61-67, 1983.

32. Mostafavi, H, Khaksarian M, Joghataei MT, et al: Selective $\beta 2$ adrenergic agonist increases Cx43 and miR-451 expression via cAMP-Epac. Mol Med Rep 9: 2405-2410, 2014.

33. Salameh A, Krautblatter S, Karl S, et al: The signal transduction cascade regulating the expression of the gap junction protein connexin43 by beta-adrenoceptors. Br J Pharmacol 158: 198-208, 2009.

34. Lu Y, Zhang Y, Shan H, et al: MicroRNA-1 downregulation by propranolol in a rat model of myocardial infarction: a new mechanism for ischaemic cardioprotection. Cardiovasc Res 84: 434-441, 2009.
35. Hanstein R, Trotter J, Behl C and Clement AB: Increased connexin 43 expression as a potential mediator of the neuroprotective activity of the corticotropin-releasing hormone. Mol Endocrinol 23: 1479-1493, 2009.

36. Curcio A, Torella D, Iaconetti C, et al: MicroRNA-1 downregulation increases connexin 43 displacement and induces ventricular tachyarrhythmias in rodent hypertrophic hearts. PLoS One 8: e70158, 2013.

37. Hegi ME, Rajakannu P and Weller M: Epidermal growth factor receptor: a re-emerging target in glioblastoma. Curr Opin Neurol 25: 774-779, 2012

38. Katakowski M, Zheng X, Jiang F, Rogers T, Szalad A and Chopp M: MiR-146b-5p suppresses EGFR expression and reduces in vitro migration and invasion of glioma. Cancer Invest 28: 1024-1030, 2010.

39. Ueki T, Fujita M, Sato K, Asai K, Yamada K and Kato T: Epidermal growth factor down-regulates connexin-43 expression in cultured rat cortical astrocytes. Neurosci Lett 313: 53-56, 2001.

40. Shi J, Zhang L, Shen A, et al: Clinical and biological significance of forkhead class box O 3 a expression in glioma: mediation of glioma malignancy by transcriptional regulation of p27kip1. J Neurooncol 98: 57-69, 2010.

41. D'Urso PI, D'Urso OF, Storelli C, et al: miR-155 is up-regulated in primary and secondary glioblastoma and promotes tumour growth by inhibiting GABA receptors. Int J Oncol 41: 228-234, 2012.

42. Qiu S, Lin S, Hu D, Feng Y, Tan Y and Peng Y: Interactions of miR-323/miR-326/miR-329 and miR-130a/miR-155/miR-210 as prognostic indicators for clinical outcome of glioblastoma patients. J Transl Med 11: 10, 2013.

43. Liu S, Yang Y and Wu J: TNF $\alpha$-induced up-regulation of miR-155 inhibits adipogenesis by down-regulating early adipogenic transcription factors. Biochem Biophys Res Commun 414: 618-624, 2011.

44. Johnstone SR, Best AK, Wright CS, Isakson BE, Errington RJ and Martin PE: Enhanced connexin 43 expression delays intra-mitotic duration and cell cycle traverse independently of gap junction channel function. J Cell Biochem 110: 772-782, 2010.

45. Huang RP, Fan Y, Hossain MZ, Peng A, Zeng ZL and Boynton AL: Reversion of the neoplastic phenotype of human glioblastoma cells by connexin 43 (cx43). Cancer Res 58: 5089-5096, 1998. 